\title{
Celiac Disease and Adherence to Gluten Free Diet; an Outpatient View
}

\author{
Dina IS ${ }^{1}$, Safaa $\mathrm{H} \mathrm{T}^{2}$, and Heba $\mathrm{SA}^{3}$ \\ ${ }^{1} \mathrm{MD}$ in Ped., ${ }^{2} \mathrm{PhD}$ childhood studies, ${ }^{3} \mathrm{PhD}$ Nutrition \\ ${ }^{\mathbf{1}, 2,3}$ Clinical Nutrition Department, National Nutrition Institute (NNI), Cairo, Egypt
}

\section{ABSTRACT}

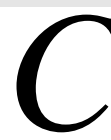

Veliac disease (CD) seems to be a considerable health disorder in Egypt. However, no full data on patients' current situation concerning main presentation, tools commonly used for diagnosis, extent of adherence to gluten free diet (GFD), and long-term monitoring plan. This study was undertaken to investigate these important management issues. Design: A convenient sample of 72 records was selected for those who were referred to the outpatient clinic of National Nutrition Institute (NNI) for prescribing a gluten-free diet for them and attended nutrition education sessions at NNI.Data was collected to evaluate patients' current situation concerning main presenting manifestations, tools commonly used for diagnosis, and extent of adherence to gluten free diet. Results: $72.0 \%$ of cases were mainly in infancy and childhood age and number of referred girls/females was nearly double that of boys/males. Vomiting/diarrhea represented main manifestations (63.0\%) and weight loss/failure to thrive was the next common (31.0\%). Anemia was also common (25.0\%). Anti-tissue transglutaminase IgA (anti-tTG) IgA (46.0\%) and endoscopy (40.0\%) were the main investigating tools.Duodenal biopsy was takenin $22.0 \%$ out of these $40.0 \%$ and villous lesion of various degrees was reported in only $22.0 \%$ out of these 40.0\%. Quantitative assessment of Gluten Free Diet (GFD) adequacy showed multiple micronutrients' insufficiency. Consumption of apparent and hidden gluten sources was dramatically decreased following the nutrition education and training sessions. The shortage in availability of gluten-free products and their high cost were among main obstacles. Conclusion and Recommendations: The only treatment for celiac disease, at present, is a strict gluten-free diet for life. There is an urgent need to increase awareness among primary health care physicians and pediatricians about the wide diversity of clinical manifestations and the role of serological testing in the diagnosis of celiac disease.Governmental support for providing GF products is mandatory for proper GF adherence and for improving nutrients' adequacy.

Keywords: CDpresentation CDscreening gluten-restricted diet 


\section{Introduction:}

$\mathrm{CD}$ is an immunemediated systemic disorder elicited by gluten and related prolamines in genetically susceptible individuals and characterized by the presence of a variable combination of gluten-dependent clinical manifestations, CD-specific antibodies, HLA-DQ2 or HLADQ8 haplotypes, and enteropathy.

CD-specific antibodies comprise autoantibodies against tissue transglutaminase 2TG2, including endomysial antibodies (EMA), and antibodies against deamidated forms of gliadin peptides (DGP).(Husby et al, 2012)

The only treatment for $\mathrm{CD}$ is a gluten-free diet (GFD). Wheat-gluten proteins include gliadins and glutenins. The closely related proteins in barley and rye that activate $\mathrm{CD}$ are hordeins and secalins, respectively. The gliadins are subdivided into $\alpha / \beta, \gamma$, and $\omega$ gliadins, while the glutenins consist of low molecular weight (LMW) and high molecular weight (HMW) glutenins.
Gluten has high concentrations of glutamine and proline residues (35 and $15 \%$ of the total amino acid content). High proline content renders these proteins resistant to complete proteolytic digestion by gastric, pancreatic, and brush border enzymes in the human intestine, since these enzymes are deficient in prolyl endopeptidase activity, making it possible for large immunogenic gluten peptides to accumulate and reach the mucosal surface. (Pozo, et al, 2012)

Several classifications of $\mathrm{CD}$ have been used, most important with distinctions drawn among classical, atypical, asymptomatic, latent, and potential CD. Because atypical symptoms may be considerably more common than classic symptoms, the ESPGHAN working group decided to use the following nomenclature: gastrointestinal symptoms and signs (e.g., chronic diarrhea) and extra-intestinal symptoms and signs (e.g., anemia, neuropathy, decreased bone density, increased risk of fractures).(Husby, et al, 2012) 
The prevalence of the disorder is globally $1 \%$, but wide variations between countries have been shown (Lionetti, et al, 2011). Many reports have shown that celiac disease is a common disorder in North Africa (Catassi, et al, 1999), the Middle East (Lionetti, et al, 2011), India (Sood et al, 2006), and Pakistan (Aziz, et al, 2007).In Intertropical Africa, celiac disease has been reported especially in Djibouti and Sudan (Mohammed, et al, 2006; Ageep 2012; and Diallo, and Coton 2013).

Celiac disease seems to be a frequent disorder among Egyptian children, both in the general population $(0.53 \%)$ and in at-risk groups (6.4\%), data do not support the theory of a Middle East-Europe CD prevalence gradient secondary to the pattern of agriculture spreading from the so-called Fertile Crescent. (Abu Zikrey, et al, 2008)

However, no full data on patients' current situation concerning main presentation, tools commonly used for diagnosis, extent of adherence to gluten free diet, and long-term monitoring plan. So, aim of this study was to investigate these important management issues.

\section{Subjects \&Methods:}

\section{Subjects}

A convenient sample of 72 records was selected for patients who were referred to the outpatient clinic of NNI from year 2010 to year 2015 for prescribing a gluten-free diet for them.

\section{Methods}

Data collected was concerned with symptoms at presentation, diagnostic tools commonly used, and anthropometric assessment for those who had attended for the first visit.

Diet adherence, symptoms improvement, and post-diet Laboratory assessment for those who had follow up visits.

Adequacy of nutrients' Intake was based on recommendations of Food and Nutrition Board, Institute of Medicine, National Academies (2005) and analysis of diet was based on a computer 
program using NNI Food Composition Tables (2006).

Nutritional status was based on BMI calculation using the following equation: $\mathbf{B M I}=$ weight (kg) / Height2 (meter). Results were standardized using growth curves of WHO (2006) and CDC (2000). Stunting results were based on Z-score for height (less than 2SD below reference population) up to age 18 years (Total of 52 records and height was not recorded for 7 cases).

\section{Statistical Analysis:}

Data was analyzed using SPSS version 13" program and was presented as \% frequency distribution and proportions for categorical data according to (Sendcor and Cochran, 1979).

\section{RESULTS \& DISCUSSION:}

Table (1) showed personal and nutritional status data. Results showed that $72.0 \%$ of patients were mainly in infancy and childhood age and the number of referred girls/females was nearly double that of boys/males as in other autoimmune disorders. Based on BMI results, majority was in the normal BMI category with some tendency $(20.0 \%)$ to be an overweight/obese and $40.0 \%$ of them were stunted. The femaleto-male ratio has been variably reported, with prospective population studies rating from 1: 3 to 1.5: 1. Celiac disease is now known to affect all age groups, including the elderly; more than $70 \%$ of new patients are diagnosed above the age of 20 years (Tortora, et al, 2016)

Table (2) showed main presenting manifestations. It was clear from table that Vomiting/diarrhea represented main manifestation $(63.0 \%)$ and weight loss/failure to thrive (FTT) was the next common (31.0\%). Anemia was also a common finding (25.0\%). Arthritis/Osteoporosis was reported in $12.5 \%$ of cases. Autoimmune disorders common to associate celiac and reported in this study were; Type $1 \mathrm{DM}$ (7 cases), thyroiditis (1 case), and chronic hepatitis ( 1 case). 
Patients with classic celiac disease presented with signs and symptoms of malabsorption, including diarrhea, steatorrhea, and weight loss or growth failure (NICE, 2009).In non-classic celiac disease, patients may present with nonspecific gastrointestinal symptoms without signs of malabsorption, or with extra intestinal manifestations (without gastrointestinal symptoms) (Santonicola, et al, 2011). The prevalence of nonclassic celiac disease is high in the Western world, with patients mainly presenting with unexplained iron-deficiency anemia.

Table (3) showed investigations usually done to diagnose or exclude Celiac disease.

Anti-tissue transglutaminase IgA was done for $(46.0 \%)$ of cases and endoscopy was carried out in (40.0\%). However, duodenal biopsy was taken in only $22.0 \%$ of all biopsies and villous lesion of various degrees was reported in $22.0 \%$ of biopsied cases.

As first-line tests for symptomatic and asymptomatic patients, the experts suggest anti-tissue transglutaminase (anti-tTG) $\operatorname{Ig} \mathrm{A}+$ total $\operatorname{Ig} \mathrm{A}$. However, to confirm a positive first test, or in case of borderline a-tTG IgA titers, it is recommended that other tests should be added. Other immunoassays regarded as good tests include anti-endomysium antibody (EMA) and either a positive IgA-transglutaminase 2 (TG2) test or positive IgGdeamidated gliadin peptide (DGP) test. The combination of IgG-DGP and IgA-TG2 is particularly useful as an addition, to detect patients with $\mathrm{CD}$ who are IgA-deficient. IgGDGP is reported to be able to detect a few more IgA-sufficient patients who are missed on IgATG2 tests. For some authors, performing IgA-tTG + IgG-DGP — two tests addressing different antigens - is better than if two tests addressing the same autoantigen (IgA-tTG $+\operatorname{Ig} \mathrm{A}$ EMA) are carried out. IgA endomysial antibody testing is moderately sensitive (around $80 \%$ ) and has the highest specificity of all celiac diseasespecific tests (with close to 
$100 \%$ specificity if performed by experienced operators) for untreated celiac disease (active) (Giersiepen, et al, 2012; Rostom, et al, 2005). Clinical research has shown that this assay has a very high level of diagnostic accuracy in high-risk and low-risk populations. This has been confirmed in the study of Sugai and his co-workers (2010)

Antibody tests against native gliadin (AGA-IgA or AGA-IgG) are neither sensitive nor specific for celiac disease and should not be used (Giersiepen, et al, 2012).

\section{Figures 1 to 4} summarized adequacy of glutenfree diet used by study cases as regards macro- and micronutrients' content. Food records of 27 cases on GFD were analyzed using NNI food composition table (2006). Adequacy of nutrients' intake was based on recommendations of Food and Nutrition Board, Institute of Medicine, National Academies (2005). Further categorization of nutrient adequacy into unsafe, inadequate, adequate, and over- consumption was defined based on WHO/FAO (2004).

Figure 1: Nearly half of cases were categorized as an over-consumer for fat and carbohydrates (i.e. calories from fat exceeded $30.0 \%$ of total caloric intake per day and calories from carbohydrates exceeded $60.0 \%$ of total caloric intake per day). In contrast, protein consumption was inadequate in $70.0 \%$ of records (i.e. calories from protein were below $15 \%$ of total calories). Overall caloric consumption was evaluated as being inadequate in $41.0 \%$ of records and $15.0 \%$ were exceeding their caloric recommendations.

Figure 2: Macrominerals' Intake showed high consumption of sodium in $56.0 \%$ of records and in $26.0 \%$ of phosphorus. In contrast intakes of potassium, calcium, and magnesium were unsafe (less than $50.0 \%$ of recommended daily allowances; RDA).

Figure 3: Adequacy of micro-minerals' Intake showed that iron adequacy (daily intake $75 \%$ to $120 \%$ RDA) was 
reported for nearly one fifth of records compared to $41.0 \%$ for zinc and $15.0 \%$ for copper. The other face of the coin; inadequacy (less than $75 \%$ of RDA), was present in $52.0 \%$, $30.0 \%$, and $27.0 \%$ for these same minerals respectively. Copper intake in half the records was in the over-consumption range.

Figure 4: Intake of vitamin A was less than $50.0 \%$ of recommended daily allowance. Nearly one third of records were also low in B-complex intake.

It is important that patients with celiac disease consume a well-balanced diet including vitamins, calcium, and fibers, with specialist consultation.

Table (4 and 5) evaluated the degree of adherence to gluten-free diet using an evaluation list. (CDF, 1998-2018) Consumption of apparent and hidden gluten sources was dramatically decreased following the nutrition education and training sessions.
The only treatment for celiac disease, at present, is a strictly gluten-free diet for life (Marsh, et al, 1992; Ciclitira, et al, 2001; Green and Cellier 2007; Ciacci, et al 2015).Patients with celiac disease should not eat products containing wheat, rye, or barley. Patients usually need to follow a strictly gluten-free diet for the rest of their lives. A small subgroup of patients with celiac disease (fewer than 5\%) may also be intolerant to pure oats, and an oat-free diet is therefore not recommended, at least during the first 3 months of treatment (Janatuinen, et al, 1995 and 2000).

Table (6): showed main obstacles that could significantly affect management plan as documented by cases: among main obstacles were the shortage in availability of gluten-free products and their high cost. Also no proper follow up was reported in form of periodical lab measurements mainly due to high cost of these investigations as mentioned by patients.

In summary, the worldwide distribution of 
Dina S, Safaa H T, and Heba S

gluten-containing foods, predisposing genotypes, and factors involved in the pathogenesis of celiac disease are likely to be responsible for the widespread and almost universal emergence of the disorder.

The ratio of diagnosed to undiagnosed cases of celiac disease varies from country to country (one to two in Finland, one to 10 in the United States, Argentina, and Germany) (Fasano and Catassi, 2001; Gomez, et al, 2001; Mäki et al, 2003; Green, 2005). This suggests that without active screening most cases of celiac disease would remain undetected.

\section{Conclusion}

\section{recommendations:}

The only treatment for celiac disease, at present, is a strict gluten-free diet for life. There is an urgent need to increase awareness among primary health care physicians and pediatricians about the wide diversity of clinical manifestations and the role of serological testing in the diagnosis of celiac disease.

Governmental support for providing GF products is mandatory for proper GF adherence and for improving nutrients' adequacy.

\section{REFERENCES:}

Abu Zekry M; Kryszak D; Diab M; Catassi C and Fasano A (2008):

Prevalence of celiac Disease in Egyptian children disputes the east west agriculturedependent Spread of the disease. $J$ Pediatr Gastroenterol Nutr; 47:136-140.

Ageep AK (2012):

Celiac disease in the Red Sea state of Sudan. Trop Gastroenterol;33(2):118 -22 .

Aziz S; Muzaffar R; Zafar MN; Mehnaz A; Mubarak M; Abbas Z; Naqvi SA and Rizvi AH ( 2007):

Celiac disease in children with persistent diarrhea and failure to thrive. J Coll Physicians Surg Pak; 17(9):554-7.

Catassi C; Rätsch IM; Gandolfi L; Pratesi R; Fabiani 
E; El Asmar R; Frijia M; Bearzi I and Vizzoni $L$ (1999):

Why is coeliac disease endemic in the people of the Sahara? Lancet 354(9179):647-8.

Celiac disease Foundation (CDF) (1995-2018):

Pediatric celiac disease follow-up.

Centers for Disease Control and Prevention (CDC) (2000):

Growth charts for the United States: improvements to the 1977 National Center for Health Statistics version. Ogden CL1, Kuczmarski RJ, Flegal KM, Mei Z, Guo S, Wei $\mathrm{R}$, Grummer-Strawn

LM, Curtin LR, Roche

AF, Johnson CL.

Ciacci C; Ciclitira P; Hadjivassiliou M; Kaukinen K; Ludvigsson JF; McGough N; Sanders DS; Woodward J; Leonard JN and Swift GL (2015):

The gluten-free diet and its current application in coeliac disease and dermatitis herpetiformis. United EurGastroenterol $J ; 3(2): 121-35$.
Ciclitira PJ; King AL and Fraser JS (2001):

AGA technical review on Celiac Sprue. American Gastroenterological

Association

Gastroenterology;

120(6):1526-40.

Diallo I and Coton T (2013):

Celiac disease: a challenging disease uneasy to diagnose in Sub-Saharan Africa. J Gastroenterol Hepatol Res [Internet]; 2(8):753-6. Available at: http://www.ghrnet.org/index .php/joghr/article/view/459.

Fasano A and Catassi C (2001):

Current approaches to diagnosis and treatment of celiac disease: an evolving spectrum. Gastroenterology; 120(3):636-51.

Food and Nutrition Board, (2005):

Institute of Medicine, National Academies

Giersiepen K; Lelgemann M; Stuhldreher N; Ronfani L; Husby S; Koletzko S; Korponay-Szabo IR and the ESPGHAN Working Group 
on Coeliac Disease Diagnosis (2012;):

Accuracy of diagnostic antibody tests for coeliac disease in children: summary of an evidence report.

PediatrGastroenterolNutr 54(2):229-41.

Green PHR and Cellier C. (2007):

Celiac disease. $N$ Engl $J$ Med; 357(17):1731-43.

\section{Green PHR (2005):}

The many faces of celiac disease: clinical presentation of celiac disease in the adult population.

Gastroenterology; $\quad 128(4$ Suppl 1):S74-78.

Gomez JC; Selvaggio GS; Viola M; Pizarro B; la Motta G; de Barrio S; Castelletto R; Echeverría R; Sugai $\mathrm{E}$; Vazquez $\mathrm{H}$; Mauriño $\mathrm{E}$ and Bai JC (2001):

Prevalence of celiac disease in Argentina: screening of an adult population in the La Plata area. Am J Gastroenterol ;96(9):2700 4.

Husby S; Koletzko S; Korponay Szabo'; IR, Mearin ML; Phillips A; Shamir R; Troncone $\quad \mathrm{R}$; Giersiepen $\mathrm{K}$;
Branski D; Catassi

C; Lelgeman M; Mäki M; Ribes-Koninckx C; Ventura A; Zimmer KP; ESPGHAN Working Group on Coeliac Disease Diagnosis; ESPGHAN

Gastroenterology

Committee; (2012):

European Society for Pediatric Gastroenterology, Hepatology, and Nutrition guidelines for the diagnosis of coeliac disease. $J$ Pediatr Gastroenterol Nutr; 54:136-160.

Janatuinen EK; Pikkarainen PH; Kemppainen TA; Kosma VM; Järvinen RM; Uusitupa MI; and Julkunen RJ (1995):

A comparison of diets with and without oats in adults with celiac disease. $\mathrm{N}$ Engl J Med;333:1033-7.

Janatuinen EK; Kemppainen TA; Pikkarainen PH; Holm K H; Kosma V-M; Uusitupa M I J; Mäki M,; and Julkunen R J K (2000):

Lack of cellular and humoral immunological responses to oats in adults with coeliac disease. Gut;46:327-31.

Lionetti E and Catassi C (2011): 
New clues in celiac disease epidemiology, pathogenesis, clinical manifestations, and treatment. Int Rev Immunol;30(4):219-31.

Mäki M; Mustalahti K; Kokkonen J; Kulmala P; Haapalahti M; Karttunen T; Ilonen J; Laurila K; Dahlbom I; Hansson T; Höpfl P and Knip M. (2003):

Prevalence of Celiac disease among children in Finland. N Engl J Med; 348 (25): 2517-24.

Marsh MN (1992):

Gluten major histocompatibility complex and the small intestine. Amolecular and immunobiologic approach to the spectrum of gluten sensitivity ("celiac sprue"). Gastroenterology;102(1):33 0-54.

\section{Mohammed IM; Karrar ZEA} and El-Safi SH. (2006;):

Coeliac disease in Sudanese children with clinical features suggestive of the disease. East Mediterr Health J 12(5):582-9.

National Institute for Health and Care Excellence (NICE) (2009:
Celiac Disease. Recognition and Assessment of Celiac Disease. London,

\section{National Nutrition institute} (2006):

Food Composition Table for Egypy, 2nd ed. Cairo, A.R.E.

Pozo Rubio T; Olivares M; Nova E; De Palma G; Mujico JR; Ferrer MD; Marcos A and Sanz Y ( 2012):

Immune development and intestinal microbiota in celiac disease. Clin Dev Immunol; 654143.

Rostom A; Dubé C; Cranney A; Saloojee N; Sy R; Garritty C; Sampson M; Zhang L; Yazdi F; Mamaladze V; Pan I; MacNeil J; Mack D; Patel D and Moher D (2005):

The diagnostic accuracy of serologic tests for celiac disease: a systematic review. Gastroenterology; 128(4 Suppl 1):S38-46.

Santonicola A; Iovino P; Cappello C; Capone P; Andreozzi $P$ and Ciacci C(2011):

From menarche to menopause: the fertile life span of celiac women. 
Menopause; 18(10):112530.

Sendcor G and Cochran W (1979):

Statistical method 6th ed. Lowa state collage U. S. A: 841.

Sood A; Midha V; Sood N; Avasthi $G$ and Sehgal $A(2006)$ :

Prevalence of celiac disease among school children in Punjab, North India. $J$ Gastroenterol Hepatol; 21(10):1622-5.

Sugai E; Moreno ML; Hwang HJ; Cabanne A; Crivelli A; Nachman F; Vázquez $\mathbf{H}$; Niveloni S; Argonz J; Mazure R; La Motta G; Caniggia ME; Smecuol E; Chopita N; Gómez JC; Mauriño E and Bai JC (2010):

Celiac disease serology in patients with different pretest probabilities: is biopsy avoidable? World $J$ Gastroenterol 16(25):314452.
Tortora R; Zingone F; Rispo A; Bucci C; Capone P; Imperatore $\mathbf{N}$; Caporaso $\mathrm{N}$; D'Agosto $\mathrm{D}$ and Ciacci $\mathrm{C}$ (2016):

Coeliac disease in the elderly in a tertiary centre. Scand J Gastroenterol 51(10):1179-83.

WHO (World Health Organization) /FAO (food Agriculture Organization) (2004):

Vitamin and mineral requirements in human nutrition; Second edition.

\section{WHO (World Health} Organization) (2006):

Child growth standards: length/height-for-age, weight-for-age, weight-forheight and body mass indexfor-age: Methods and development. Geneva, Switzerland: World Health Organization; Available at http://www.who.int/childgr owth/publications/technical _report_pub/en/index.html 
Table (1): Personal and Anthropometric Data:

\begin{tabular}{|c|c|c|c|}
\hline Criteria & $\begin{array}{c}\text { Boy/Male (25) } \\
\text { No. Row \% }\end{array}$ & $\begin{array}{c}\text { Girl/Female } \\
(47) \\
\text { No Row \% }\end{array}$ & $\begin{array}{l}\text { Total (72) } \\
\text { Column \% }\end{array}$ \\
\hline $\begin{array}{l}\text { 1. Age: } \\
=<5 \text { years } \\
\text { School age } \\
\text { Adolescenc } \\
\text { e } \\
\text { Adult }\end{array}$ & $\begin{array}{c}13(65.0 \%) \\
10(50.0 \%) \\
1(8.0 \%) \\
1 \quad(5.0 \%)\end{array}$ & $\begin{array}{cc}7 & (35.0 \%) \\
10 & (50.0 \%) \\
11 & (92.0 \%) \\
19 & (95.0 \%)\end{array}$ & $\begin{array}{l}20(28.0 \%) \\
20(28.0 \%) \\
12(16.0 \%) \\
20(28.0 \%)\end{array}$ \\
\hline $\begin{array}{l}\text { 2. Nutritional } \\
\text { Status:* } \\
\text { Over/obese } \\
\text { Normal } \\
\text { Under-nutrition } \\
\\
\text { Stunting }^{* *}\end{array}$ & $\begin{array}{c}0(0.0 \%) \\
20(41.0 \%) \\
1(50.0 \%) \\
8(44.0 \%)\end{array}$ & $\begin{array}{cc}13 & (100.0 \%) \\
29 & (59.0 \%) \\
1 & (50.0 \%) \\
& \\
10 & \\
& \end{array}$ & $\begin{aligned} 13 & (20.0 \%) \\
49 & (77.0 \%) \\
2 & (3.0 \%) \\
& \\
18 & (40.0 \%)\end{aligned}$ \\
\hline
\end{tabular}

* Nutritional status was based on BMI calculation and referred to both WHO (2005) and CDC growth curves (2000).

** Stunting results were based on Z-score for height (less than 2SD below reference population) up toage 18 years (Total of 52 records and height was not reported for 7 cases) 
Table (2): Main Presenting Manifestations:

\begin{tabular}{|c|c|c|c|}
\hline Manifestation & $\begin{array}{l}\text { Age }=<12 \text { y } \\
\quad(40) \\
\text { No. } \stackrel{\text { Row \% }}{ }\end{array}$ & $\begin{array}{l}\text { Age }>12 \text { y } \\
\quad(32) \\
\text { No. } \quad \text { Row \% }\end{array}$ & $\begin{array}{r}\text { Total } \\
(72) \\
\text { No. Row \% }\end{array}$ \\
\hline $\begin{array}{l}\text { Weight loss/ FTT } \\
\text { Vomiting/ Diarrhea } \\
\text { Distension/colic }\end{array}$ & $\begin{array}{ll}11 & 27.5 \% \\
22 & 55.0 \% \\
3 & 7.5 \%\end{array}$ & $\begin{array}{rr}11 & 34.0 \% \\
23 & 72.0 \% \\
2 & 6.0 \%\end{array}$ & $\begin{array}{rr}22 & 31.0 \% \\
45 & 63.0 \% \\
91 & 3.0 \%\end{array}$ \\
\hline $\begin{array}{l}\text { Iron deficiency IDA } \\
\text { DM type I } \\
\text { Arthritis/Osteoporosis } \\
\text { (OP) } \\
\text { Hypothyroidism } \\
\text { Chronic Hepatitis } \\
\text { Depression }\end{array}$ & $\begin{array}{lr}5 & 12.5 \% \\
2 & 5.0 \% \\
3 & 7.5 \% \\
0 & 0.0 \% \\
0 & 0.0 \% \\
0 & 0.0 \%\end{array}$ & $\begin{array}{ll}13 & 41.0 \% \\
5 & 16.0 \% \\
6 & 19.0 \% \\
1 & 3.0 \% \\
1 & 3.0 \% \\
2 & 6.0 \%\end{array}$ & 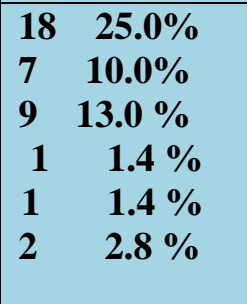 \\
\hline
\end{tabular}

Table (3): Tools used for diagnosis:

\begin{tabular}{|c|c|c|c|c|}
\hline Tool & $\begin{array}{c}\text { Age }=<12 \\
\text { yr(40) } \\
\text { No. Row } \\
\%\end{array}$ & $\begin{array}{c}\text { Age > 12 } \\
\text { yr(32) } \\
\text { No. Row \% }\end{array}$ & \multicolumn{2}{|c|}{$\begin{array}{c}\text { Total(72) } \\
\text { No. Row } \\
\%\end{array}$} \\
\hline aTTG $^{*}>20 \mathrm{EU} / \mathrm{ml}$ & $215 \quad 2.5 \%$ & $1340.6 \%$ & 34 & 47.0 \\
\hline EMA $^{* *}$ & $3 \quad 7.5 \%$ & $26.0 \%$ & & 57.0 \\
\hline $\operatorname{IgA}$ & $92 \quad 2.5 \%$ & $515.6 \%$ & 14 & 19.0 \\
\hline Anti-gliadin & $615.0 \%$ & $4 \quad 12.5 \%$ & 10 & 14.0 \\
\hline Endoscopy & $1332.5 \%$ & $1650.0 \%$ & 29 & 40.0 \\
\hline Duodenal biopsy & $615.0 \%$ & $1031.0 \%$ & 16 & 22.0 \\
\hline Villous lesion & $82 \quad 0.0 \%$ & $825.0 \%$ & 16 & 22.0 \\
\hline $\begin{array}{l}\text { Both } \\
\text { aTTG \& Endoscopy }\end{array}$ & $1127.5 \%$ & $34.0 \%$ & 22 & 31.0 \\
\hline
\end{tabular}

* anti-tissue transglutaminase ** anti-endomyasial antibody 
Dina S, Safaa H T, and Heba S
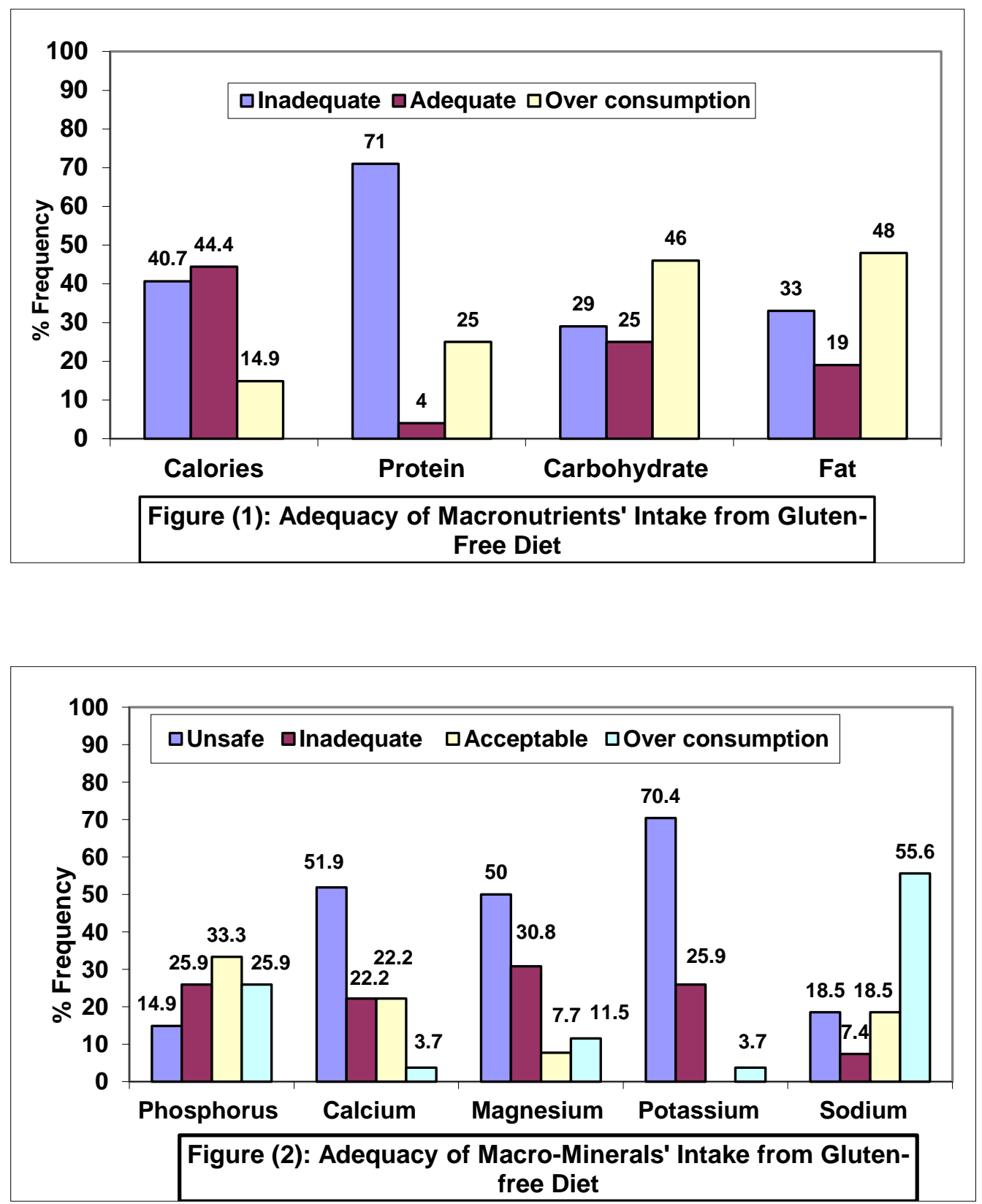
Dina S, Safaa H T, and Heba S
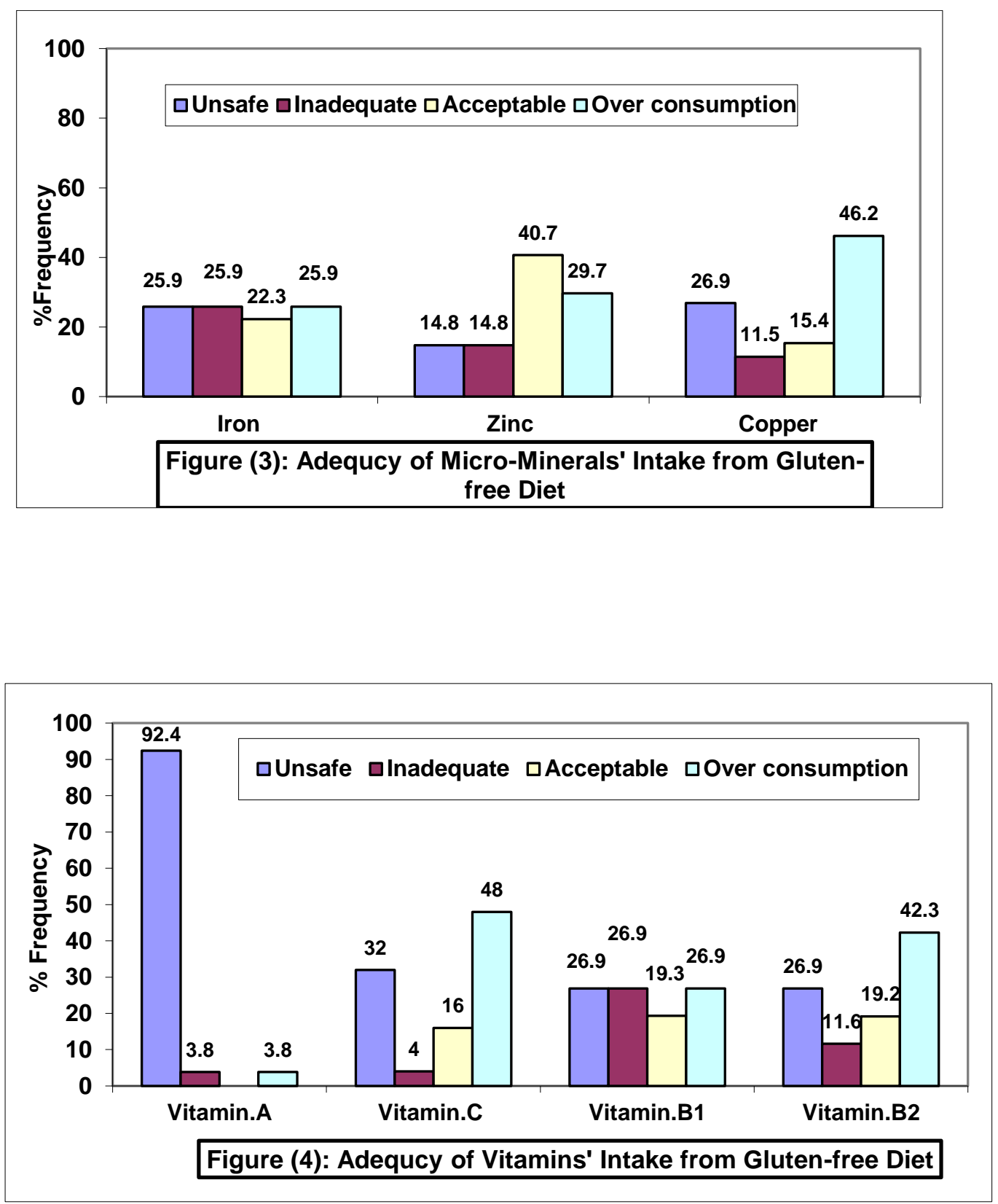
Table (4): Gluten-restricted Diet Adherence (Apparent Gluten sources):

\begin{tabular}{|l|l|l|l|l|l|}
\hline \multirow{2}{*}{ Food Item } & \multicolumn{2}{l}{ Total(27) } & \multirow{2}{*}{ Post-gluten restriction } & \multicolumn{2}{l|}{ Total (27) } \\
\cline { 3 - 4 } & \multirow{2}{*}{ Nood Item } & \multirow{2}{*}{ restriction } & & \multicolumn{2}{l|}{} \\
\cline { 3 - 6 } & & & & No & $\%$ \\
\hline Macaroni & 17 & 68.0 & Macaroni & 0 & 0.0 \\
\hline French bread & 15 & 60.0 & French bread & 0 & 0.0 \\
\hline Biscuits & 10 & 40.0 & Biscuits & 0 & 0.0 \\
\hline Balady bread & 15 & 60.0 & Balady bread & 0 & 0.0 \\
\hline Cake & 8 & 32.0 & Cake & 0 & 0.0 \\
\hline Pizza & 8 & 32.0 & Pizza & 0 & 0.0 \\
\hline Bread sticks & 8 & 32.0 & Bread sticks & 0 & 0.0 \\
\hline Bakery & 6 & 24.0 & Bakery & 0 & 0.0 \\
\hline Noodles (Endomy) & 6 & 24.0 & Noodles (Endomy) & 0 & 0.0 \\
\hline Fiteer & 7 & 28.0 & Fiteer & 0 & 0.0 \\
\hline Koskosi & 4 & 16.0 & Koskosi & 0 & 0.0 \\
\hline Wheat flour & 5 & 20.0 & Wheat flour & 1 & 3.4 \\
\hline $\begin{array}{l}\text { Wheat } \\
\text { (belila) }\end{array}$ & 2 & 8.0 & Wheat grains (belila) & 0 & 0.0 \\
\hline Wheat bran & 2 & 8.0 & Wheat bran & 1 & 3.4 \\
\hline Semolina & 1 & 4.0 & Semolina & 0 & 0.0 \\
\hline
\end{tabular}


Table (5): Gluten-restricted Diet Adherence (hidden Gluten sources):

\begin{tabular}{|c|c|c|c|c|c|}
\hline \multicolumn{3}{|c|}{ Pre-gluten restriction } & \multicolumn{3}{|c|}{ Post-gluten restriction } \\
\hline \multirow{2}{*}{ Food Item } & \multicolumn{2}{|c|}{ Total(27) } & \multirow{2}{*}{ Food Item } & \multicolumn{2}{|c|}{ Total(27) } \\
\hline & No & $\%$ & & No & $\%$ \\
\hline Canned Juice & 22 & 88.0 & Canned Juice & 10 & 34.5 \\
\hline Beans (Marked) & 24 & 96.0 & Beans (Marked) & 6 & 10.7 \\
\hline Processed cheese & 24 & 96.0 & Processed cheese & 8 & 27.6 \\
\hline Gum & 21 & 84.0 & Gum & 10 & 34.5 \\
\hline Chocolate & 16 & 64.0 & Chocolate & 1 & 3.4 \\
\hline Yeast & 19 & 76.0 & Yeast & 0 & 0.0 \\
\hline Fish fried & 18 & 72.0 & Fish fried & 1 & 3.4 \\
\hline Fried meat (Boftake) & 18 & 72.0 & Fried meat (Boftake) & 0 & 0.0 \\
\hline Chicken stock & 10 & 40.0 & Chicken stock & 0 & 0.0 \\
\hline Katchap & 13 & 52.0 & Ketchup & 3 & 10.3 \\
\hline Spices (vegetar) & 5 & 20.0 & Spices (vegetar) & 0 & 0.0 \\
\hline White souse & 4 & 16.0 & White souce & 0 & 0.0 \\
\hline Barley drinks & 10 & 40.0 & Barley drinks & 3 & 10.3 \\
\hline $\begin{array}{l}\text { Drinkchocolate(Nesqui } \\
\text { ck) }\end{array}$ & 8 & 32.0 & $\begin{array}{l}\text { Drinkchocolate(Nesqu } \\
\text { ick) }\end{array}$ & 1 & 3.4 \\
\hline Whipped Cream & 4 & 16.0 & Whipped Cream & 0 & 0.0 \\
\hline Burger & 4 & 16.0 & Burger & 0 & 0.0 \\
\hline Sausage & 3 & 12.0 & Sausage & 0 & 0.0 \\
\hline Kofta fried & 3 & 12.0 & Kofta fried & 0 & 0.0 \\
\hline Milk chocolate & 3 & 12.0 & Milk chocolate & 0 & 0.0 \\
\hline Fried chicken (Nagets) & 3 & 12.0 & Fried chicken (Nagets) & 1 & 3.4 \\
\hline Mustarda & 3 & 12.0 & Mustarda & 1 & 3.4 \\
\hline Falmank cheese & 1 & 4.0 & Falmank cheese & 1 & 3.4 \\
\hline Nutella & 1 & 4.0 & Nutella & 1 & 3.4 \\
\hline Cooking Cream & 1 & 4.0 & Cooking Cream & 0 & 0.0 \\
\hline
\end{tabular}


Table (6): Main Obstacles that significantly affect management plan:

\begin{tabular}{|l|r|r|}
\hline \multicolumn{1}{|c|}{ Obstacle } & \multicolumn{1}{c|}{ No } & \multicolumn{1}{|c|}{$(\%)$} \\
\hline Gluten-free Products : & & \\
\hline Availability (unavailable) & 8 & $(24.1)$ \\
Cost (high cost) & 12 & $(27.6)$ \\
Taste/Acceptability (inacceptable) & 2 & $(6.9)$ \\
Stability (fragmented) & 4 & $(13.8)$ \\
\hline CD specific Lab tests:(high cost) & 8 & $(27.6)$ \\
\hline Disease nature: (poor patients' compliance) & & \\
\hline Others: & 3 & $(10.3)$ \\
GF Products and Lab tests (unavailable \&high & 2 & $(6.9)$ \\
cost) & 1 & $(3.4)$ \\
GF Products \&unavailability of specialized doctor & 1 & $(3.4)$ \\
GF Products \&Disease nature & & \\
Disease nature \&unavailability of specialized & & \\
doctor & & \\
\hline
\end{tabular}




\section{مرض التحسس من القمح والإلتزام بحمية تقييل الجلوتين \\ دينا ابراهيم شهاب - صفاء الحسيني توفيق - هبة سعيدعبد الحليم \\ قسم التغذية الاكلينيكية - المعهد القومي للتغذية ـ القاهرة - مصر \\ الملخص العربي}

يعد مرض التحسس من القهح مشكلة صحية ذات بال في مصرإلا أنه لا تتوافر بيانات

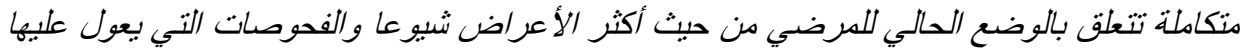

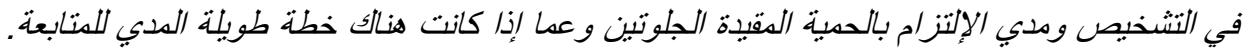

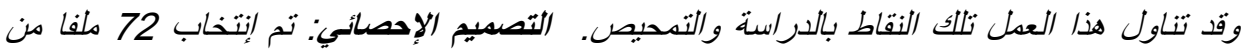

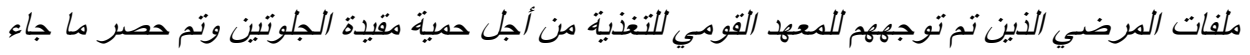

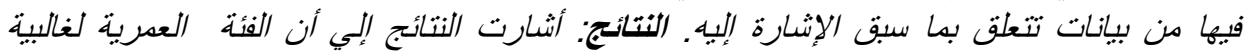

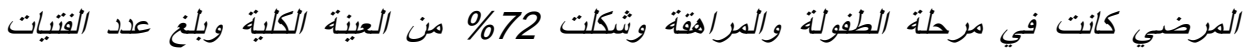

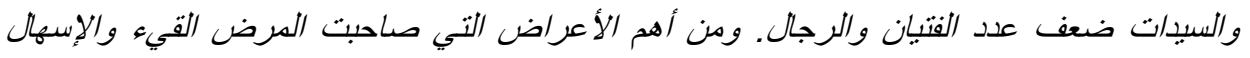

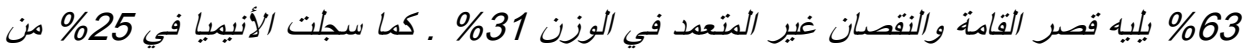

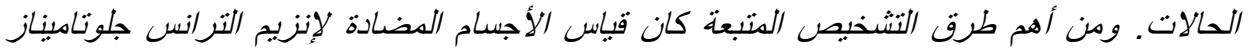

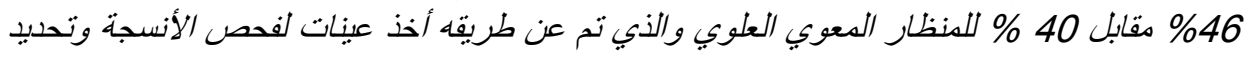
مدي الإصابة. وشكلت عينات فحص الإثنا عشر نسبة 22\% من النسبة السابقة وتم تسجيل

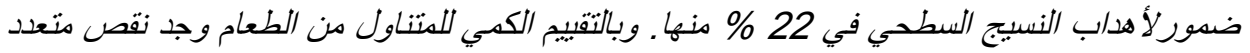

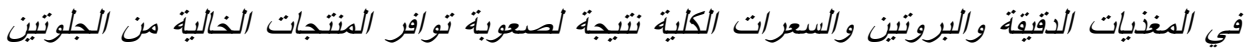

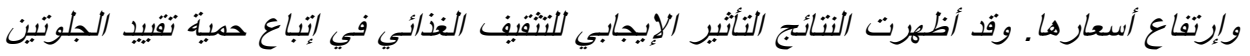

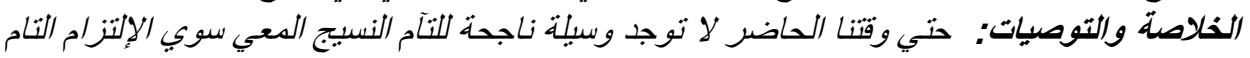

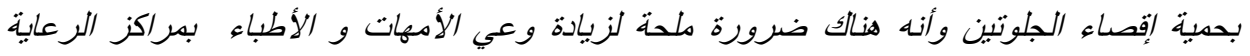

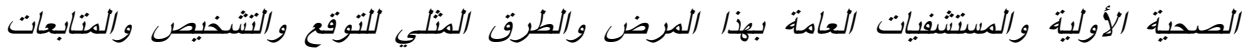

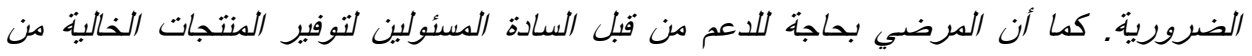

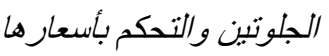
الكلمات المفتاحية : عرض التحسس من القدح - عرض الحمية الغذائية لتحسس القدح 